\title{
Nocturnal singing by diurnal birds in Afrotropical highlands
}

\author{
Michał Budka ${ }^{1}\left[\right.$ ] Anna Skierczyńska ${ }^{1} \cdot$ Marcin Antczak ${ }^{1} \cdot$ Tomasz S. Osiejuk $^{1}$ (i)
}

Received: 12 July 2020 / Revised: 20 October 2020 / Accepted: 6 November 2020 / Published online: 12 January 2021

(c) The Author(s) 2021

\begin{abstract}
Most bird species are active by day. However, even typically diurnal species have been observed to sing by night, although the functions and mechanisms of this behaviour are not well understood. In our study, we focused on nocturnal singing by diurnal birds in Afrotropical highlands (Bamenda Highlands, Cameroon). We recorded 48-h soundscapes in 18 random recording sites using autonomous sound recorders to examine the occurrence and intensity of nocturnal singing among diurnal birds. We applied three definitions of night—-the time period between: (1) astronomical, (2) nautical and (3) civil dusk and dawn, which may include or exclude beginning of dawn chorus from the night-time period. We recorded 53 bird species, representing seven orders and 27 families. Of 50 typically diurnal species, only three sang by astronomical night, producing in total 10 songs. Applying the nautical night definition did not change the meaning of the results- the same three species produced 12 vocalisations. By civil night, 21 species were recorded singing. From the analysed 2128 vocalisations produced by civil night, 2109 were produced during $25 \mathrm{~min}$ period between nautical and civil dawn (22-47 min before sunrise), what suggests that civil night covers the beginning of dawn chorus and should not be considered as a nighttime. Our study reveals that in Afrotropical highlands, unlike in temperate regions, diurnal birds stay silent at night. Using astronomical and nautical definition of night gives similar results. The intensive singing recorded between nautical and civil dawn (included into nautical night), we interpreted as the beginning of dawn chorus rather than true night singing. We suggest that precise definition of nighttime is required to compare the results of different studies and to better understand the phenomenon of night singing by diurnal birds.
\end{abstract}

Keywords Night singing $\cdot$ Dawn chorus $\cdot$ Dusk chorus $\cdot$ Song activity $\cdot$ Tropics $\cdot$ Birds of Africa

\section{Zusammenfassung}

\section{Nächtlicher Gesang tagaktiver Vögel im afrotropischen Hochland}

Die meisten Vogelarten sind tagsüber aktiv. Allerdings kann man auch bei typischerweise tagaktiven Vogelarten nächtlichen Gesang beobachten, obwohl die Funktionen und Mechanismen dieser Verhaltensweise nicht hinreichend erforscht sind. Unsere Studie konzentrierte sich auf nächtlichen Gesang tagaktiver Vögel im afrotropischen Hochland (Bamenda-Hochland, Kamerun). Mittels autonom arbeitender Aufnahmegeräte erstellten wir 48-stündige Klanglandschaften an 18 zufällig ausgewählten Orten, um Auftreten und Intensität nächtlichen Gesangs bei tagaktiven Vögeln zu untersuchen. Wir arbeiteten mit drei Definitionen des Nachtbegriffes - die Zeitspanne zwischen (1) astronomischer, (2) nautischer und (3) bürgerlicher Abend- beziehungsweise Morgendämmerung, wobei der Beginn des morgendlichen Vogelkonzerts in die Nachtperiode

Communicated by F. Bairlein.

Electronic supplementary material The online version of this article (https://doi.org/10.1007/s10336-020-01842-0) contains supplementary material, which is available to authorized users.

Michał Budka

m.budka@amu.edu.pl

1 Department of Behavioural Ecology, Adam Mickiewicz University, Uniwersytetu Poznańskiego 6, 61614 Poznan, Poland 
fallen kann oder nicht. Wir dokumentierten 53 Vogelarten aus sieben Ordnungen beziehungsweise 27 Familien. Von 50 typischerweise tagaktiven Vogelarten sangen nur drei während der astronomischen Nacht, und zwar insgesamt zehn Gesänge. Bei Anwendung des nautischen Nachtbegriffes änderte sich nicht an den Ergebnissen-dieselben drei Arten lieferten zwölf Gesänge. Während der bürgerlichen Nacht sangen 21 Vogelarten. Von den 2128 ausgewerteten Lautäußerungen im Laufe der bürgerlichen Nacht erklangen 2109 während der 25-minütigen Zeitspanne zwischen nautischer und bürgerlicher Morgendämmerung (22-47 min vor Sonnenaufgang), was nahelegt, dass die bürgerliche Nacht den Beginn des morgendlichen Vogelkonzertes einschließt und somit nicht als Nachtzeit angesehen werden sollte. Unsere Studie zeigt, dass—anders als in gemäßigten Breiten-tagaktive Vögel im afrotropischen Hochland während der Nacht schweigen. Die Anwendung des astronomischen und des nautischen Nachtbegriffes lieferte ähnliche Resultate. Die intensive Gesangsaktivität im Zeitraum zwischen nautischer und bürgerlicher Morgendämmerung (zur nautischen Nacht gerechnet) verstehen wir eher als den Beginn des morgendlichen Vogelkonzertes denn als echten nächtlichen Gesang. Wir finden, dass eine präzise Definition des Nachtbegriffs vonnöten ist, um die Ergebnisse verschiedener Studien vergleichbar zu machen und das Phänomen nächtlichen Gesangs tagaktiver Vögel besser verstehen zu können.

\section{Introduction}

The majority of bird species sing by day, with two distinct peaks of vocal activity: around sunrise (dawn chorus) and sunset (dusk chorus) (Catchpole and Slater 2008). However, recent studies have shown that even typically diurnal species also vocalise at what is for them an atypical time-at night (La 2012; Perrault et al. 2014; Kułaga and Budka 2020). It remains to be determined, however, how common this behaviour is across bird taxa. In most cases, only single observations have been reported of diurnal birds singing at nighttime, which does not provide a complete picture of such behaviour. To the best of our knowledge, nocturnal vocalisations by diurnal birds have been widely studied only in North America and Central Europe. In the North America, night singing has been found in 106 species of Passeriformes, representing 22 of 38 families examined (La 2012). Similar results were reported for Central Europe, where night singing has been reported for 24 bird species from 88 analysed (Kułaga and Budka 2020). These result suggests that night singing by diurnal birds may be more widespread than previously thought, at least in temperate region.

In most typically diurnal species that also sing at night, the intensity of night singing is generally rather low-individuals usually produce only a few songs per night (e.g., White-throated Sparrow (Zonotrichia albicollis) and Ovenbird (Seiurus aurocapilla) (Perrault et al. 2014); Field Sparrow (Spizella pusilla) (Celis-Murillo et al. 2016). However, there are also examples of a completely different pattern, such as that reported from the Nightingale (Luscinia megarhynchos), whose males produce hundreds of songs during the night as well as during the day (Amrhein et al. 2002). The existence of clear behavioural differences among diurnal bird species with respect to night singing-occasional singing, intensive singing, or no singing at all-prompt the question of why species vary in their nocturnal singing activity, both with respect to the mechanisms underlying this behaviour as well as to its function.
Regardless of the part of the day in which songs are produced, the main functions of bird songs are territory defence, mate attraction, pair bonding, reproductive stimulation, and mate guarding (Catchpole and Slater 2008). In the context of night singing by diurnal birds, the most interesting question seems to be: how does such a behaviour increase the fitness of an individual? In diurnal birds, eye anatomy strongly constrains daily patterns of activity, including the start time of singing in the morning and the end of singing in the evening (Thomas et al. 2002). Thus, any activity by diurnal birds in periods of low-intensity light should be risky for them. However, some diurnal species do undertake this risk, remaining active at night (Ward et al. 2014). La (2012) proposed a few hypotheses to explain the mechanism and functions of nocturnal singing by diurnal birds. Nocturnal vocalisations may be simply prompted by elevated light levels at night (e.g., moonlight, artificial light). In a similar way, the natural increase in light in the morning induces the start of dawn singing in birds (Silva and Kempenaers 2017). It, therefore, follows that night singing should be observed more frequently in species that vocalise early in a dawn chorus and inhabit open habitats and urban areas (La 2012). Alternatively, some species may vocalise at night to avoid acoustic competition from heterospecific or anthropogenic sources of sound (Stanley et al. 2016; Sierro et al. 2017). In this case, night singing should be observed more often in habitats that are noisy during the day and silent at night. In addition, weather conditions at night may enhance sound transmission (lower temperature, higher humidity, weaker winds; Schäfer et al. 2017), so with the same amount of energy expended for signal production a bird may be able to reach more receivers. However, in environments where the range of diurnal temperatures is extremely broad (e.g., mountains, deserts), low nighttime temperatures may limit the activity of birds, including singing, because the metabolic costs of activity at this time are too high. Similar behaviour is also observed in a 
dawn chorus-males start singing later when the preceding night was colder (Naguib et al. 2019). Night singing may also be a strategy to minimise predation risk, and in that case should be observed in locations or species that experience strong predation pressure during the day and have a lower risk at night (La 2012). Another possible explanation for night singing, especially for those species that sing only irregularly and sporadically at night, is that night songs may be produced by disquieted individuals after awakenings caused by various kinds of disturbance.

These hypotheses for the mechanism and function(s) of nocturnal singing by diurnal birds are not mutually exclusive, and the factors responsible may vary both between as well as within species. For example, a given species may be identified as a night singer in one study but not in another (La 2012; Perrault et al. 2014), suggesting that the intensity of night singing may vary seasonally and/or depend on the current status of the singer. Alternatively, ecological interactions with the environment and other organisms may induce night singing by diurnal species in one location and the absence of this behaviour in other contexts (La 2012; Perrault et al. 2014). However, inconsistencies among existing reports of night singing by the same diurnal species could also derive from the use of different definitions of nighttime: as the time between civil, nautical, or astronomical dusk and dawn. Under different definitions of night, a various length of a night-time period is analysed. The differences, dependently on the geographical latitude, may reach from several dozen minutes to a few hours, or even a typical night may not be observed in far north or south. What more, using various definitions of night causes that periods with various intensity of lighting are included or excluded from nighttime, in consequence, the beginning of the dawn chorus and ending of the dusk chorus are either included or excluded from the night period. The dawn chorus typically begins 30-90 min before sunrise and is characterised by high song rate of many bird species (Staicer et al. 1996; Gil and Llusia 2020). Including or excluding this period from the nighttime may bias the evaluation of presence and intensity of nocturnal singing - the same songs may be included or excluded from a night-time period. Thus, given the current state of knowledge, it is first important to examine: (1) how many diurnal bird species vocalise at night, (2) how intensively they sing, and (3) how widespread night singing by diurnal birds is across different regions and habitats of the world (La 2012). All of these research tasks should be conducted with a single, clearly defined period of night to enable comparison between different studies.

In our study, we focused on nocturnal singing by diurnal birds in Afromontane habitats. We focused on four main questions: (1) which diurnal bird species sing at night? (2) How does the twilight cut-off use for defining night influence the number of species singing? (3) How intensive is nocturnal singing by diurnal species? (4) What is the temporal pattern of nocturnal singing activity? We used autonomous sound recorders to collect 48-h recordings in 18 recording sites, and manual spectrogram scanning to detect songs of particular bird species.

\section{Methods}

\section{Study site}

We conducted our study in the Bamenda Highlands, near the village of Big Babanki (North-West Region, Cameroon; coordinates: N6.090594; E10.298807). The Bamenda Highlands are known to be rich in African endemic and/ or restricted-range birds (BirdLife International 2019). This region experiences two seasons: a short dry season from November to February and a long wet season from March to October (Tye 1986). The annual rainfall oscillates around $2100 \mathrm{~mm}$ (Tye 1992). Our study area (ca. $4 \mathrm{~km}^{2}$ ) was covered by a mosaic of highland habitats: fragments of upper montane rainforests, woodlands, forest clearings, stream corridors, shrub vegetation, pastures, and abandoned lands under succession by shrubs and ferns.

\section{Field data}

We used the Song Meter SM2 (Wildlife Acoustics) autonomous sound recorder to record soundscapes in 18 recording sites distributed among various habitat types in our study area (from open areas to forests). Recording sites were distributed randomly. The average distance between neighbouring recording sites was $287 \mathrm{~m}$ (range from 89 to $630 \mathrm{~m}$; the closest recording sites were located at different sites of crest of a hill, thus soundscape did not overlap). Recording sites were located at elevations from 1824 to $2340 \mathrm{~m}$ a.s.l. Recorders were attached to trees and shrubs ca. $2-5 \mathrm{~m}$ above ground. In each recording site, the recorder collected data continuously for $48 \mathrm{~h}(48.0 \mathrm{kHz}, 16$-bit sampling, mono recording; $6 \mathrm{~h} \times 8$ recordings in each recording site; two continuous nights recorded). We collected data from November 17 to December 12, 2010 (two recorders, 14 recording sites sampled) and from November 16 to November 18, 2011 (four recorders, four recording sites sampled). We sampled different recording sites in different years. The period of our study (November-December) is assumed to be the peak of the breeding season for most of the bird species that inhabit this region (Tye 1992; Sedláček et al. 2007). For the exact locations of recording sites, see Appendix 1. in ESM 


\section{Bioacoustic analyses}

We restrictively defined night as a time period between astronomical dusk and dawn. The astronomical dusk begins when the Sun falls 18 degrees below the horizon while ends when the Sun rises 18 degrees below the horizon. During this time, the sky is absolutely dark. In our location and study period, astronomical dusk started between 19:11 and 19:20 (72-74 min after sunset; local time) and ended between 04:56 and 05:04 (72-75 min before sunrise). The duration of astronomical night ranged from $9 \mathrm{~h}$ and $44 \mathrm{~min}$ to $9 \mathrm{~h}$ and $45 \mathrm{~min}$.

Additionally, we applied two alternative and less restrictive definitions of night: the time between (1) nautical dusk and dawn (the Sun 12 degrees below the horizon) and (2) civil dusk and dawn (the Sun 6 degrees below the horizon). In our location and study period, the nautical night was 50-53 min longer than astronomical night, while civil night was 100-105 min longer than astronomical night. At the beginning and at the end of nautical or civil night, the sky is variously affected by the lighting of the Sun. Therefore, we suspected that nautical or civil twilight may contain enough natural sunlight for some species to start singing, and in consequence may cover the beginning of dawn and the end of dusk chorus. In our location astronomical, nautical and civil dawn begun on average 73, 47, 22 min before the sunrise. Assuming that dawn chorus typically begins 30-90 min before sunrise (Staicer et al. 1996), we can be sure that civil night covered while astronomical and nautical night may cover the beginning of a dawn chorus in our location. Time of dusk, dawn, sunset, and sunrise was determined for each recording site and date separately, using an online calculator (https://www.timeanddate.com). See Appendix 1 in ESM for details.

Recordings were analysed using Avisoft SAS Lab Pro 5.2.13 software. We generated spectrograms with the following settings: FFT length $=1024$; frame size $=75 \%$; window $=$ Hamming; Overlap $=50 \%$. Spectrograms were listened and scanned manually. Analysing recordings, we identified each distinguishable song or equivalent of song in non-songbirds to the species of origin and noted the start time of the vocalisation. We did not analyse typical calls, defined as short, simple vocalisations, which are related to specific functions such as flight, threat, alarm (Catchpole and Slater 2008). For typically nocturnal species, such as owls, francolins, and nightjars, we did not count each song but simply noted the first one produced by astronomical night, to show that this species was present at the recording site. In our study, we recorded three such species: Black-shouldered Nightjar (Caprimulgus nigriscapilaris) Freckled Nightjar, (Caprimulgus tristigma) and Scaly Francolin (Pternistis squamates).
We also analysed the daytime recordings to determine which diurnal bird species were present at each recording site. In each recording site, we selected three 5-min daytime periods for each day of recording: (1) at sunrise, (2) $1 \mathrm{~h}$ after sunrise, and (3) $2 \mathrm{~h}$ after sunrise. In total, in each recording site, we analysed $30 \mathrm{~min}$ of daytime recordings $(3 \times 5$ min per day $\times 2$ days; term "daytime" refers to this 30-min survey). This approach enabled us to estimate the species present in each recording site during the day. Species recorded in this time were defined as diurnal. The list of diurnal species is important to know which of them vocalise at night and which are present but stay silent.

During both day- and night-time periods we recorded some vocalisations that we were not able to identify to species or higher taxon (13 types of vocalisations). These vocalisations were excluded from the analyses.

\section{Statistical analyses}

First, we calculated an average number of all bird species detected per recording site during daytime and night together. Then we identified these diurnal species, which were recorded at least once singing by astronomical, nautical, or civil night-time periods.

To examine how common is nocturnal singing by a particular diurnal species, we calculated percent of recording sites in which the species was recorded singing at night in comparison to the number of recording sites at which the species occurred (i.e., was detected at least once at recording site by daytime and night).

Intensity of nocturnal singing was calculated as the number of songs produced per recording site per night. We included to the analyses only these recording sites and theses nights in which at least one nocturnal vocalisation of a particular species was recorded. Thus, when at recording site, we recorded nocturnal singing of a particular species during the first night and no nocturnal singing during the second night we included in analysis only the first night. Temporal pattern of nocturnal singing activity of selected species showed when songs are produced over the course of the night. We also analysed differences in the average time of the first song for species which were recorded at least in five nights. All above-mentioned analyses were conducted using various definitions of night. In this way, we showed how such a basic issue as night definition may influence on results of the study and their interpretation.

Statistical analyses were performed in IBM SPSS Statistics 25 . All $p$ values are two-tailed. 


\section{Results}

During the study, we recorded 53 bird species, belonging to seven orders and 27 families (see Appendix 2 and 3 for the list and distribution in ESM). On average, in each recording site we found 23.3 species ( $\mathrm{SD}=4.55$; range from 14 to 31 ). Two species (Black-shouldered Nightjar and Freckled Nightjar) were recorded only at night, 29 species were recorded only during daytime, 22 species were recorded both by daytime and by civil night, and the same four species: Great Blue Turaco (Corythaeola cristata), Grey Apalis (Apalis cinerea), Common Stonechat (Saxicola torquatus), Scaly Francolin, were recorded both by daytime and by nautical and astronomical night. The Scaly Francolin was classified as a nocturnal species which calls also by day; therefore, we excluded them from typically diurnal birds.

\section{Commonness of nocturnal singing}

We found that of the 50 typically diurnal bird species recorded, three species vocalised at astronomical night, the same three species vocalised at nautical night and 21 species vocalised at civil night.

During astronomical night, we recorded Great Blue Turaco calling in one recording site from two in which occurred, Grey Apalis singing in one recording site from 18 in which occurred (6\% of recording sites), and Common Stonechat singing in four recording sites from ten in which occurred (40\% of recording sites) (Table 1).

Exactly the same three species like at astronomical night were recorded singing at nautical night. The difference was that Common Stonechat was recorded in five recording sites from 10 in which occurred (50\%, of recording sites) (Table 1).

When we applied less restrictive, civil definition of night, we found 21 typically diurnal species vocalising at civil night (Table 1). These 21 species belonged to 4 orders and
Table 1 Commonness of nocturnal singing by typical diurnal birds under three definitions of night

\begin{tabular}{|c|c|c|c|c|}
\hline Species & $\begin{array}{l}\text { Occur }(N \\
\text { points })\end{array}$ & $\begin{array}{l}\text { Det civil night } \\
(\%)\end{array}$ & $\begin{array}{l}\text { Det naut night } \\
(\%)\end{array}$ & $\begin{array}{l}\text { Det astr } \\
\text { night }(\%)\end{array}$ \\
\hline \multicolumn{5}{|l|}{ Columbiformes } \\
\hline Tambourine Dove & 14 & 36 & 0 & 0 \\
\hline \multicolumn{5}{|l|}{ Musophagiformes } \\
\hline Great Blue Turaco & 2 & 50 & 50 & 50 \\
\hline \multicolumn{5}{|l|}{ Passeriformes } \\
\hline Black-throated Apalis & 8 & 13 & 0 & 0 \\
\hline Chubb's Cisticola & 16 & 6 & 0 & 0 \\
\hline Grey Apalis & 18 & 33 & 6 & 6 \\
\hline Cinnamon-breasted Bunting & 5 & 60 & 0 & 0 \\
\hline Oriole Finch & 10 & 10 & 0 & 0 \\
\hline Yellow-breasted Boubou & 18 & 39 & 0 & 0 \\
\hline African Dusky Flycatcher & 3 & 33 & 0 & 0 \\
\hline Common Stonechat & 10 & 100 & 50 & 40 \\
\hline Snowy-crowned Robin-chat & 10 & 40 & 0 & 0 \\
\hline Northern Double-collared Sunbird & 17 & 59 & 0 & 0 \\
\hline Orange-tufted Sunbird & 10 & 30 & 0 & 0 \\
\hline Black-winged Oriole & 5 & 20 & 0 & 0 \\
\hline Bannerman's Weaver & 6 & 17 & 0 & 0 \\
\hline Cameroon Mountain Greenbul & 12 & 58 & 0 & 0 \\
\hline Common Bulbul & 18 & 61 & 0 & 0 \\
\hline Western Mountain Greenbul & 10 & 10 & 0 & 0 \\
\hline African Hill-babbler & 12 & 42 & 0 & 0 \\
\hline African Yellow White-eye & 15 & 27 & 0 & 0 \\
\hline \multicolumn{5}{|l|}{ Piciformes } \\
\hline Western Green Tinkerbird & 15 & 7 & 0 & 0 \\
\hline
\end{tabular}

Occur-number of points (from 18 analysed) in which species was recorded

Det civil night, Det naut night, Det astr night—percent of points at which species was recorded singing by civil, nautical or astronomical night, respectively

Diurnal species which were recorded singing by astronomical night are bolded 
14 families. In order Passeriformes, such defined nocturnal singing was found in 18 of 38 recorded species $(47 \%)$, belonging to 11 of 18 analysed $(61 \%)$ families. One species - the Common Stonechat, was detected more often by civil night than by daytime (Table 1).

\section{Intensity of nocturnal singing}

Three typical diurnal species vocalising by astronomical night produced in total 10 vocalisations during $350 \mathrm{~h}$ of night recordings: Great Blue Turaco-one call in one recording site; Grey Apalis - three songs in one recording site by one night; Common Stonechat-six songs in four recording sites, from one to two songs per night. These 10 vocalisations were produced on average $342 \mathrm{~min}$ before sunrise ( $\mathrm{SD}=157.1$; range $94-570 \mathrm{~min}$ before sunrise). See Fig. 1 and Table 2 for more details.

When we applied nautical night definition, the same three species like during astronomical night produced in total 12 vocalisations during $381 \mathrm{~h}$ of night recordings (Table 2). The difference was that the Common Stonechat produced eight songs in five recording sites (two more than at astronomical night; from one to two songs per night).

When we analysed civil night-time period we found 2128 songs belonging to 21 diurnal species singing by civil night. These songs were recorded during two short 25-min periods between civil and nautical dusk (seven songs belonging to one species - the Common Stonechat) and nautical and civil dawn (22-47 min before sunrise; 2109 songs belonging to 20 species). We found significant differences in an average time of the first song for species which were recorded at least in five civil nights (Kurskal-Wallis test; $H=45.183, \mathrm{df}=10$, $p<0.001$ ) (Fig. 2). The civil night-singing activity of the most widespread species in our study area is shown in Fig. 3.
Fig. 1 Singing activity of two typical diurnal bird species which were observed singing by civil night. Histograms show the total number of songs produced by a particular species in relation to a civil dawn. $N$ means during how many nights the species was recorded singing by civil night
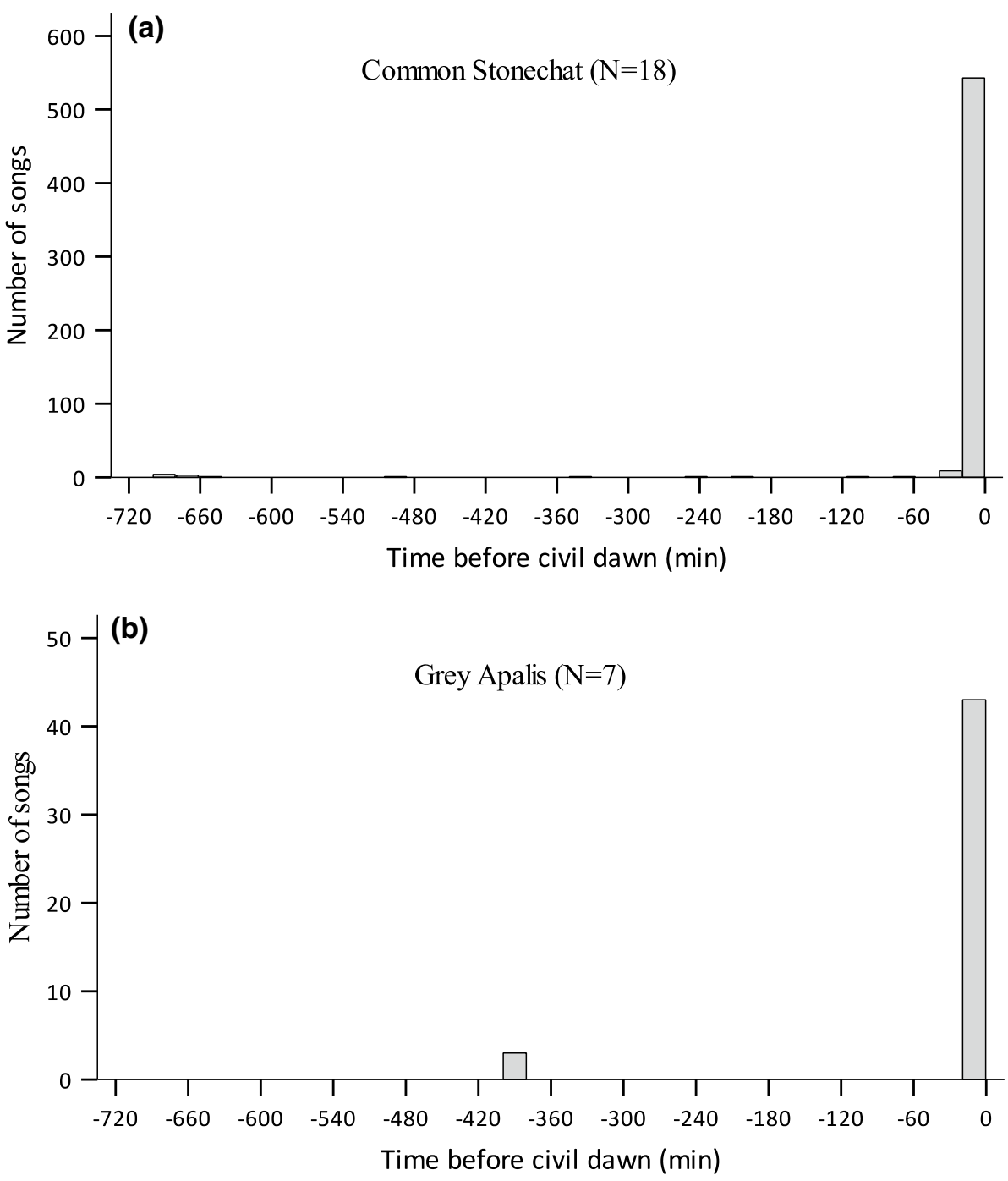
Table 2 Intensity of night singing by typically diurnal birds under three definitions of night

\begin{tabular}{|c|c|c|c|c|c|c|}
\hline Species & Civil Det & Civil Intens & Nau tDet & Naut Intens & Astr Det & Astr Intens \\
\hline \multicolumn{7}{|l|}{ Columbiformes } \\
\hline Tambourine Dove & 6 & 3.0 & 0 & 0.0 & 0 & 0.0 \\
\hline \multicolumn{7}{|l|}{ Musophagiformes } \\
\hline Great Blue Turaco & 1 & 1.0 & 1 & 1.0 & 1 & 1.0 \\
\hline \multicolumn{7}{|l|}{ Passeriformes } \\
\hline Black-throated Apalis & 2 & 12.5 & 0 & 0.0 & 0 & 0.0 \\
\hline Chubb's Cisticola & 1 & 1.0 & 0 & 0.0 & 0 & 0.0 \\
\hline Grey Apalis & 7 & 6.6 & 1 & 3.0 & 1 & 3.0 \\
\hline Cinnamon-breasted Bunting & 4 & 23.8 & 0 & 0.0 & 0 & 0.0 \\
\hline Oriole Finch & 1 & 4.0 & 0 & 0.0 & 0 & 0.0 \\
\hline Yellow-breasted Boubou & 12 & 13.6 & 0 & 0.0 & 0 & 0.0 \\
\hline African Dusky Flycatcher & 2 & 202.0 & 0 & 0.0 & 0 & 0.0 \\
\hline Common Stonechat & 18 & 31.4 & 6 & 1.3 & 5 & 1.2 \\
\hline Snowy-crowned Robin-chat & 7 & 5.3 & 0 & 0.0 & 0 & 0.0 \\
\hline Northern Double-collared Sunbird & 17 & 16.2 & 0 & 0.0 & 0 & 0.0 \\
\hline Orange-tufted Sunbird & 5 & 12.2 & 0 & 0.0 & 0 & 0.0 \\
\hline Black-winged Oriole & 2 & 7.0 & 0 & 0.0 & 0 & 0.0 \\
\hline Bannerman's Weaver & 1 & 1.0 & 0 & 0.0 & 0 & 0.0 \\
\hline Cameroon Mountain Greenbul & 9 & 6.1 & 0 & 0.0 & 0 & 0.0 \\
\hline Common Bulbul & 14 & 18.9 & 0 & 0.0 & 0 & 0.0 \\
\hline Western Mountain Greenbul & 1 & 1.0 & 0 & 0.0 & 0 & 0.0 \\
\hline African Hill-babbler & 5 & 9.6 & 0 & 0.0 & 0 & 0.0 \\
\hline African Yellow White-eye & 5 & 8.4 & 0 & 0.0 & 0 & 0.0 \\
\hline \multicolumn{7}{|l|}{ Piciformes } \\
\hline Western Green Tinkerbird & 1 & 1.0 & 0 & 0.0 & 0 & 0.0 \\
\hline
\end{tabular}

Civil Det, Naut Det, Astr Det—number of nights during which species was observed singing by civil, nautical or astronomical night, respectively; Civil Intens, Naut Intens Astr Intens-intensity of singing by civil, nautical or astronomical night, respectively. Intensity is measured as an average number of songs recorded per night. Only nights with at least one song recorded were included in analysis

Diurnal species which were recorded singing by astronomical night are bolded

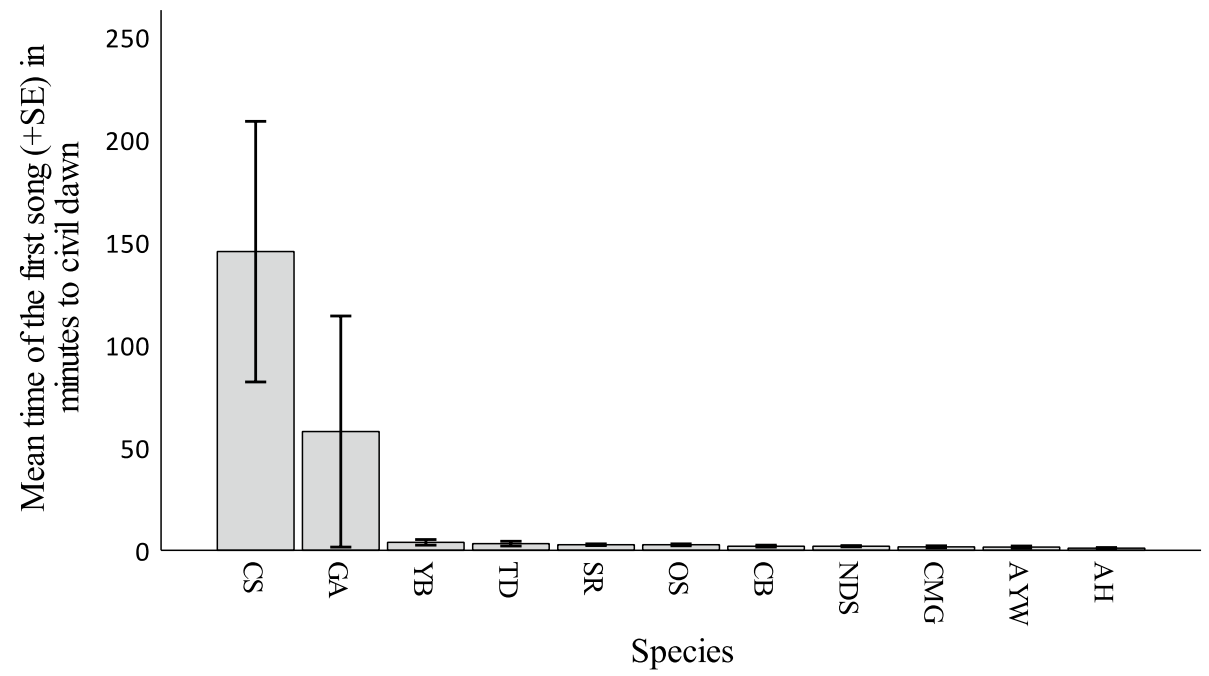

Fig. 2 Mean time of the first song measured to the civil dawn. Only species detected during more than five nights are shown. Species are presented in decreasing order. Abbreviations of species: $C S$ common stonechat $(N=18), G A$ Grey Apalis $(N=7), Y B$ Yellow-breasted Boubou $(N=12), T D$ Tambourine Dove $(N=6), S R$ Snowy-crowned
Robin-chat $(N=7), O S$ Orange-tufted Sunbird $(N=5), C B$ Common Bulbul $(N=14)$, NDS Northern Double-collared Sunbird $(N=17)$, $C M G$ Cameroon Mountain Greenbul $(N=9), A Y W$ African Yellow White-eye $(N=5), A H$ African Hill-babbler $(N=5)$ 
(a)

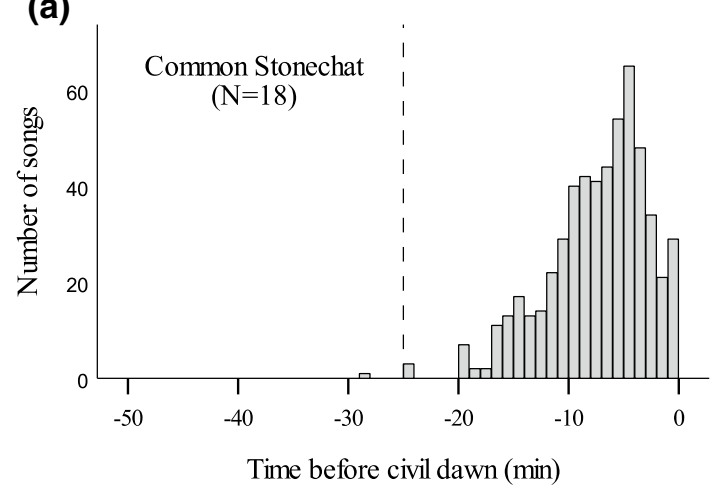

(c)

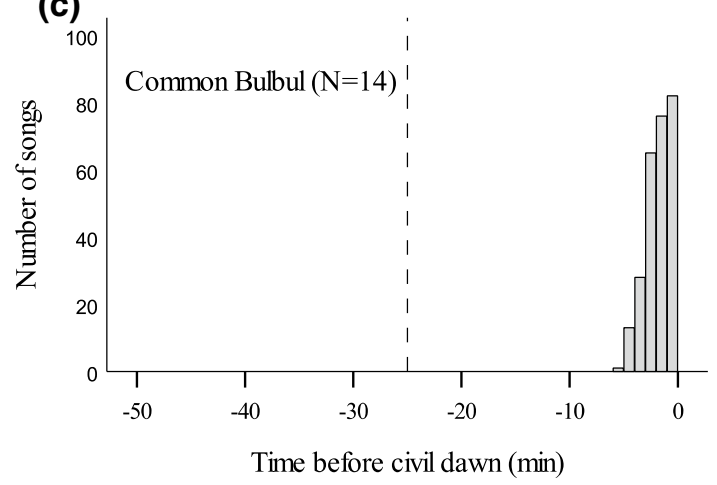

(e)

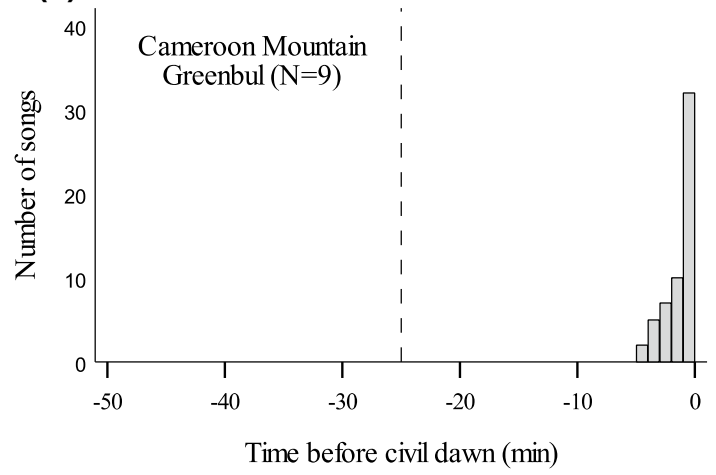

(g)

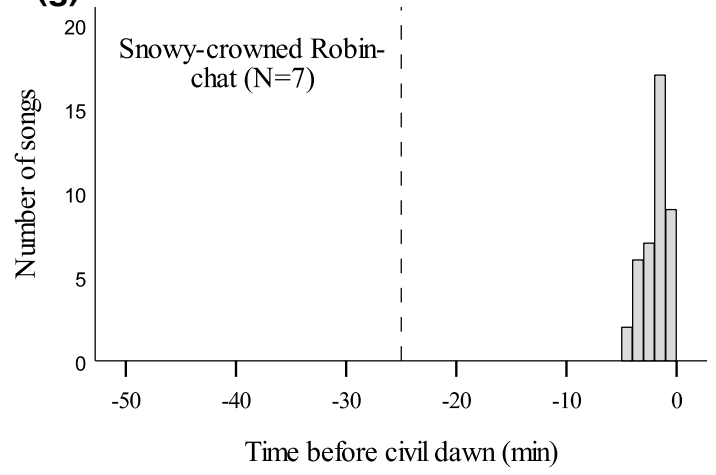

Fig. 3 Singing activity of typical diurnal birds from astronomical dawn $(-51 \mathrm{~min})$ to civil dawn $(0 \mathrm{~min})$. Histograms show the total number of songs produced by a particular species. Only species (b)

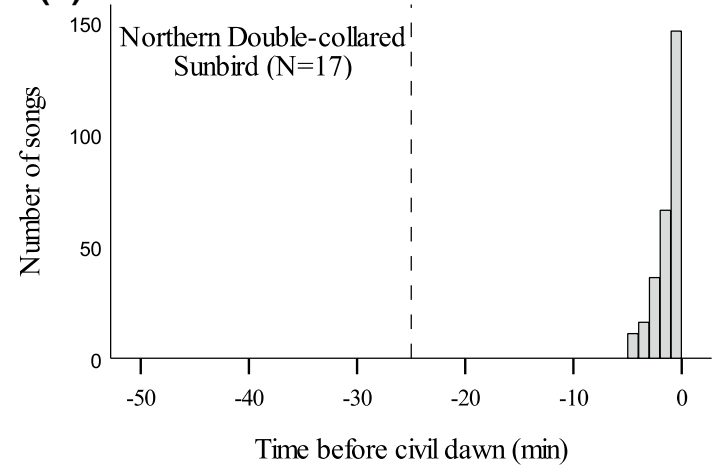

(d)
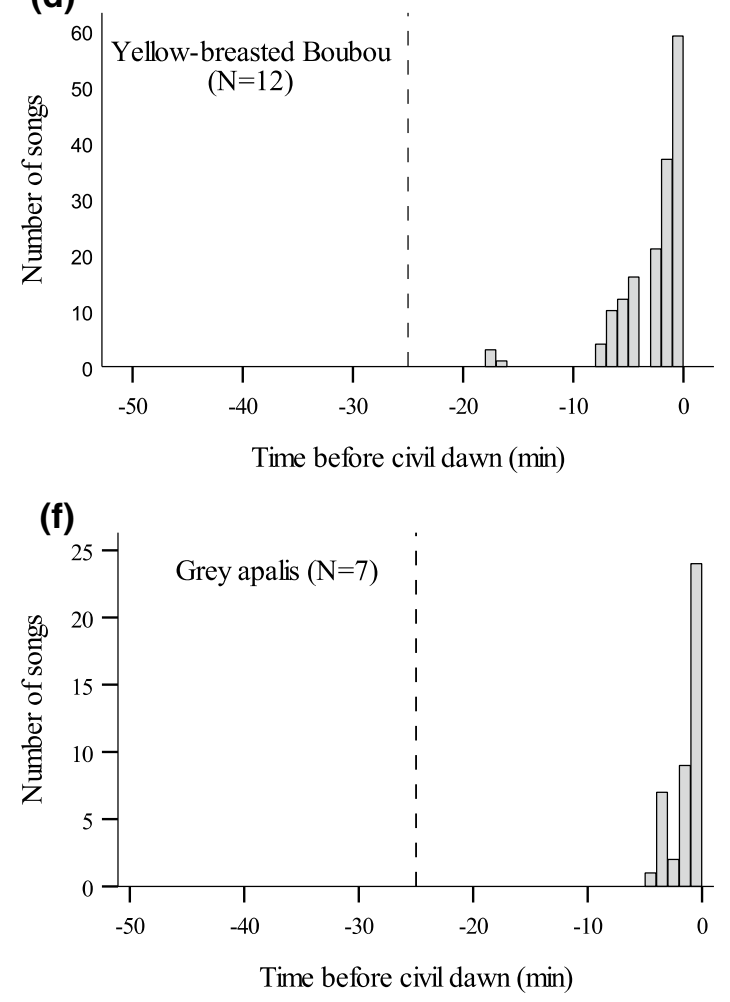

(h)

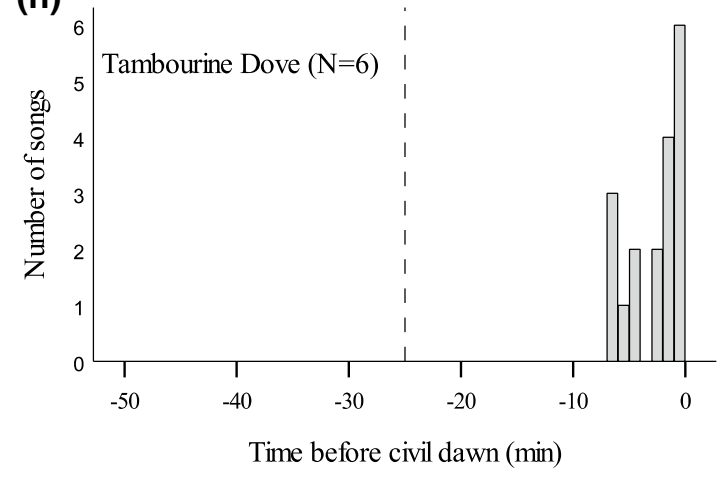

recorded during five or more civil nights are shown. The number of nights during which species was recorded is given $(N)$. Dashed line indicates the beginning of nautical dawn 

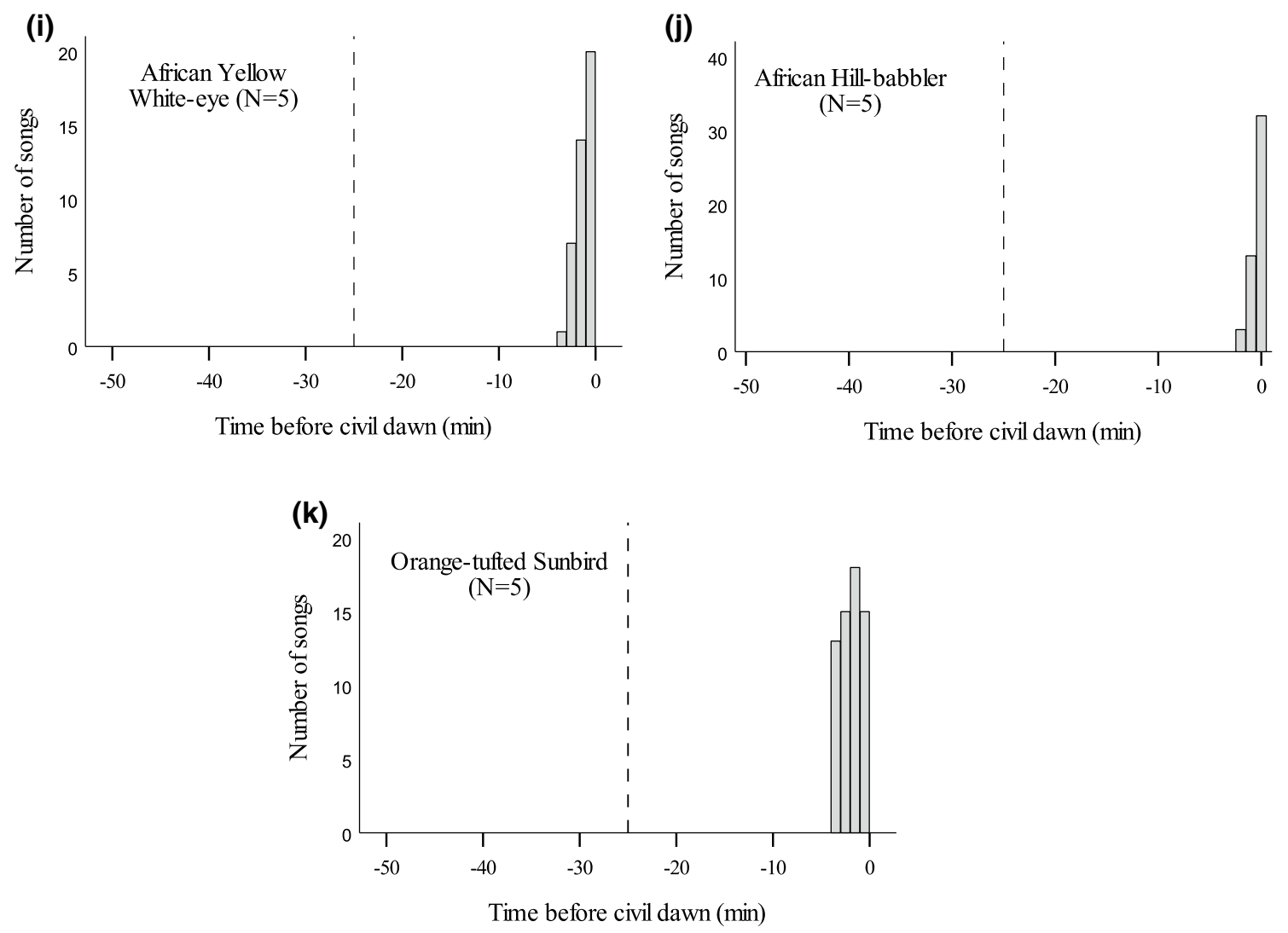

Fig. 3 (continued)

\section{Discussion}

In the majority of studies that focus on nocturnal singing by diurnal birds, only the presence and/or the intensity of nocturnal singing, measured as the number of songs per night, are generally reported (Celis-Murillo et al. 2016; La 2012; Foote et al. 2017), with very little information on the time of night in which songs are recorded (but see: Kułaga and Budka 2009; Perrault et al. 2014). To further confuse the matter, authors often do not clearly define what they mean by the term 'night', or they are inconsistent in the definitions of dawn and dusk (astronomical, nautical, or civil) that are used to distinguish nighttime (Amrhein et al. 2002; Bruni et al. 2014; Foote et al. 2017). This ambiguity may lead to an inaccurate understanding and interpretation of the mechanism and function(s) of night singing by diurnal birds, and makes it difficult to compare the results obtained by various studies. For example, of at least seven bird species defined as night-singers in North America (La 2012), only two were recorded at night when it was defined as the period between civil dusk and nautical dawn (Perrault et al. 2014). To probe these discrepancies, in our study, we analysed night singing using three definitions of night.
Using restrictive definition of night - the time between astronomical dusk and dawn-we found only three typically diurnal species that sang during astronomical night and produced in total ten vocalisations. Increasing the night length to nautical did not change the list of typically diurnal species singing by night but increased the total number of produced songs from 10 to 12 , what suggests that applying both definitions of night delivers similar results, at least in tropics. This decidedly low frequency and intensity of night singing lead us to the conclusion that, in the Afrotropical highlands, diurnal birds are almost silent at night, at least in the period analysed here which represented the peak of the breeding season (Sedláček et al. 2007). Especially when we compare it with nocturnal singing in temperate region. For example, in Central Europe during astronomical night, 24 bird species from 88 analysed have been found to sing at night. Some species produced, on average, even more than 1000 songs per recording site per night (Kułaga and Budka 2020). It is unlikely that, at such low frequency and intensity of nocturnal singing by diurnal birds in tropics, night singing confers fitness benefits on individuals by increasing reproduction or survival. For this reason, we hypothesise that this type of night singing in the Common Stonechat and Grey Apalis where birds occasionally produce $1-3$ songs per 
night represents an incidental (e.g., singing after a sudden awakening) rather than a functional behaviour.

Using civil definition of night, we found that $40 \%$ of bird species produced calls or songs between civil dusk and dawn. However, in fact, 2109 songs from 2128 recorded by civil night were produced in short period ( $25 \mathrm{~min}$ ) between nautical and civil dawn (Table 2, Fig. 3). A civil dawn started on average $22 \mathrm{~min}$ before the sunrise, and covered dawn chorus, which typically begins 30-90 minu before sunrise (Staicer et al. 1996). Therefore, observed by us singing in this time we defined as the beginning of the dawn chorus instead of night singing, during which subsequent species join the dawn chorus (Fig. 2). What is interesting, that all species stopped singing before civil dusk. We recorded only seven songs of the Common Stonechat between civil and nautical dusk (Fig. 1), what suggests that studying night singing behaviour by diurnal birds the definition of the beginning of the night is not such important as the definition of the end of the night. Depending on anatomical constraints like eye size, species join the dawn chorus when the available lighting has increased to a level that is sufficient for adequate vision (Thomas et al. 2002). For this reason, any songs between nautical and civil dawn should be considered the beginning of a dawn chorus rather than true night singing (Bruni et al. 2014). With this in mind, our results indicate that tropical highland birds start singing naturally in the morning and do not run the risk of singing at night, when the light is insufficient to be able to see effectively (Figs. 2, 3). Because tropical ecosystems are evolutionarily older than temperate ones, this suggests that, for diurnal birds, being silent at nighttime may be actually the ancestral strategy. In general, tropical birds seem to be less willing to undertake risky behaviour then temperate birds are (Ghalambor and Martin 2001), which may have its roots in the numerous biological and ecological differences between the species inhabiting these two regions. With respect to temperate birds, tropical birds demonstrate sedentariness, year-round territories, low extra-pair copulation and longlasting pair bonding, lower testosterone level, and a longer breeding season (Stuchbury and Morton 2001). Night singing by diurnal birds is similarly risky behaviour that tropical birds may try to avoid. Presumably, therefore, the Common Stonechat observed in our study produced occasionally 1-2 songs per astronomical nigh, while closely related European species- the Whinchat (Saxicola rubetra), sung on average ca 100 songs per shorter, 4-h astronomical night in Poland (Kułaga and Budka 2020).

In animals, synchronisation of circadian clocks is based mainly on the day-night cycle. Close to the equator, day and night are almost equal in duration and stable throughout the year. Such strongly periodical light-dark conditions should induce rhythmic daily patterns of physiological and behavioural processes (Yamada et al. 1988), including singing activity (Prabhat et al. 2019). In temperate zones, even over the length of a short breeding season (2-4 months), the duration of day increases noticeably, with day-time much longer than night, and in the case of the far north or south, no night at all. Some bird species adapt their daily rhythm to these conditions and are continuously active or demonstrate 'free-running', individually specific activity cycles (Steiger et al. 2013). Experimental studies on zebra finches also confirmed that periodicity in light-dark conditions induces rhythmic cycles of singing (singing during $12 \mathrm{~h}$ in the light, no singing during $12 \mathrm{~h}$ in the dark), while conditions of continuous light cause a decline in daily patterns, even resulting in completely arrhythmic singing activity (e.g., singing scattered across the 24-h period) (Prabhat et al. 2019). Thus, tropical birds' habit of staying quiet at night and singing by day is likely to be a response to their rhythmic and stable light-dark conditions, while the more-arrhythmic singing activity in some bird species in temperate zones may suggest that these species adapt their circadian clock to seasonal changes in day and night.

The study showed two main findings. The first one, behavioural, is that tropical birds in contrast to temperate ones, at least in our study location and study period, are almost completely silent at astronomical night. The observed singing activity between nautical and civil dawn, in our opinion, should be defined as a beginning of dawn chorus rather than nocturnal singing. The second one, methodological, is that clear definition of a night-time period is a critical to when studding nocturnal singing by diurnal birds. Using various definitions of night makes results of different studies incomparable, what makes difficult understanding the general mechanism and function of nocturnal singing by diurnal birds.

Acknowledgements We thank Ernest Vunan Amohlon for his help in organising field work in Cameroon and all Kedjom-Keku people for allowing to study birds on their land, Lindsay Higgins for language correction, three anonymous reviewers for helpful comments on the manuscript The study was supported by Polish National Science Centre (Grant no. 2013/08/T/NZ8/01029 to AS) and the Ministry of Science and Higher Education (Grant no. KB/62/13739/IT1-B/U/08 to TSO and no. IP2014 005073 to MB).

Open Access This article is licensed under a Creative Commons Attribution 4.0 International License, which permits use, sharing, adaptation, distribution and reproduction in any medium or format, as long as you give appropriate credit to the original author(s) and the source, provide a link to the Creative Commons licence, and indicate if changes were made. The images or other third party material in this article are included in the article's Creative Commons licence, unless indicated otherwise in a credit line to the material. If material is not included in the article's Creative Commons licence and your intended use is not permitted by statutory regulation or exceeds the permitted use, you will need to obtain permission directly from the copyright holder. To view a copy of this licence, visit http://creativecommons.org/licenses/by/4.0/. 


\section{References}

Amrhein V, Korner P, Naguib M (2002) Nocturnal and diurnal singing activity in the nightingale: correlations with mating status and breeding cycle. Anim Behav 64:939-944. https://doi.org/10.1006/ anbe. 2002.1974

BirdLife International (2019) Endemic bird areas factsheet: Cameroon mountains. Downloaded from http://www.birdlife.org on 12/09/2019

Bruni A, Mennill DJ, Foote JR (2014) Dawn chorus start time variation in a temperate bird community: relationships with seasonality, weather, and ambient light. J Ornithol 155:877-890. https://doi. org/10.1007/s10336-014-1071-7

Catchpole C, Slater PJB (2008) Bird song: Biological themes and variations. Cambridge University Press. https://doi.org/10.1017/ CBO9780511754791

Celis-Murillo A, Stodola KW, Pappadopoli B, Burton JM, Ward MP (2016) Seasonal and daily patterns of nocturnal singing in the Field Sparrow (Spizella pusilla). J Ornithol 157:853-860. https ://doi.org/10.1007/s10336-015-1318-y

Foote JR, Nanni LK, Schroeder R (2017) Seasonal patterns of nocturnal singing by ovenbirds and white-throated sparrows. Behaviour 154:1275-1295. https://doi.org/10.1163/1568539X-00003468

Ghalambor CK, Martin TE (2001) Fecundity-survival trade-offs and parental risk-taking in birds. Science 292:494. https://doi. org/10.1126/science.1059379

Gil D, Llusia D (2020) The bird Dawn chorus revisited. In: Aubin T, Mathevon N (eds) Coding strategies in vertebrate acoustic communication. Springer, Cham, pp 45-90

Kułaga K, Budka M (2020) Nocturnal singing by diurnal birds in a temperate region of central Europe. J Ornithol. https://doi. org/10.1007/s 10336-020-01794-5

La AVT (2012) Diurnal and nocturnal birds vocalize at night: A review. Condor 114:245-257. https://doi.org/10.1525/cond.2012.100193

Naguib M, Diehl J, Van OK, Snijders L (2019) Repeatability of signalling traits in the avian dawn chorus. Front Zool 16:27. https://doi. org/10.1186/s12983-019-0328-7

Perrault K, Lobert LM, Ehnes M, Foote JR (2014) Nocturnal singing in a temperate bird community. J Ornithol 155:1059-1062. https ://doi.org/10.1007/s10336-014-1077-1

Prabhat A, Jha NA, Taufique SKT, Kumar V (2019) Dissociation of circadian activity and singing behavior from gene expression rhythms in the hypothalamus, song control nuclei and cerebellum in diurnal zebra finches. Chronobiol Int 36:1268-1284. https ://doi.org/10.1080/07420528.2019.1637887

Schäfer JE, Janocha MM, Klaus S, Thomas D (2017) How weather instead of urbanity measures affects song trait variability in three European passerine bird species. Ecol Evol 7:4868-4880. https:// doi.org/10.1002/ece3.3032

Sedláček O, Reif J, Hořák D, Riegert J, Pešata M, Klvana P (2007) The birds of a montane forest mosaic in Big Babanki area, Bamenda Highlands, Cameroon. Malimbus 29:89-100
Sierro J, Schloesing E, Pavón I, Gil D (2017) European blackbirds exposed to aircraft noise advance their chorus, modify their song and spend more time singing. Front Ecol Evol 5:1-13. https://doi. org/10.3389/fevo.2017.00068

Silva A, Kempenaers B (2017) Singing from North to South: latitudinal variation in timing of dawn singing under natural and artificial light conditions. J Anim Ecol 86:1286-1297. https://doi. org/10.1111/1365-2656.12739

Staicer CA, Spector DA, Horn AG (1996) The dawn chorus and other diel patterns in acoustic signaling. In: Kroodsma DE, Miller EH (eds) Ecology and evolution of acoustic communication in birds. Cornell Univ. Press, New York, pp 426-453

Stanley CQ, Walter MH, Venkatraman MX, Wilkinson GS (2016) Insect noise avoidance in the dawn chorus of Neotropical birds. Anim Behav 112:255-265. https://doi.org/10.1016/j.anbeh av.2015.12.003

Steiger SS, Valcu M, Spoelstra K, Helm B, Wikelski M, Kempenaers B (2013) When the sun never sets: diverse activity rhythms under continuous daylight in free-living arctic-breeding birds. Proc R Soc B Lond 280:20131016. https://doi.org/10.1098/ rspb.2013.1016

Stuchbury BJM, Morton ES (2001) Behavioral ecology of tropical birds. Academic Press, London

Thomas RJ, Széskely T, Cuthill IC, Harper DGC, Newson SE, Frayling TD, Wallis PD (2002) Eye size in birds and the timing of song at dawn. Proc R Soc Lond B 269:831-837. https://doi.org/10.1098/ rspb.2001.1941

Tye H (1986) The climate of the highlands of Western Cameroon. pp: 18-19 In: Stuart SN (ed.) Conservation of Cameroon Montane Forests. International Council for Bird Preservation, Cambridge.

Tye H (1992) Reversal of breeding season by lowland birds at higher altitudes in western Cameroon. Ibis 134:154-163. https://doi. org/10.1111/j.1474-919X.1992.tb08392.x

Ward MP, Alessis M, Benson TJ, Chiavacci SJ (2014) The active nightlife of diurnal birds: extraterritorial forays and nocturnal activity patterns. Anim Behav 88:175-184. https://doi.org/10.1016/j. anbehav.2013.11.024

Yamada H, Oshima I, Sato K, Ebihara S (1988) Loss of the circadian rhythms of locomotor activity, food intake, plasma melatonin concentration induced by constant bright light in the pigeon (Columba livia). J Comapartive Physicology A 163:459-543. https://doi. org/10.1007/bf00604900

Publisher's Note Springer Nature remains neutral with regard to jurisdictional claims in published maps and institutional affiliations. 